4. Белороссова, Н.В. Клоновая селекция хмеля / Н.В. Белороссова // Труды РНИХС. - Вып. 1 «Культура хмеля». - М.: Пищепромиздат, 1954. - С. 5-38.

5. Методика проведения испытаний на отличимость, однородность, стабильность. Хмель (Humulus lupulus. L.) // Официальный бюллетень Госсорткомиссии. 2008. - № 9 (139). - С. 710-720.

6. Либацкий, Е.П. Хмелеводство / Е.П. Либацкий. - М.: Колос, 1984. - 287 с.

7. Рекомендации по определению повреждений хмеля вредителями и болезнями и мероприятия по борьбе с ними. - Киев: Урожай, 1981. - С. 5-50.

DOI $10.18699 / \mathrm{GPB} 2020-98$

\title{
Современные реалии производства ржи и задачи селекционной науки
}

Пономарева М.Л., д.б.н., профессор, г.н.с.; Пономарев С.Н.*, д.с.-х.н., г.н.с. ТатНИИСХ ФИЦ КазНЦ РАН, г.Казань, Россия.

*e-mail: smponomarev@yandex.ru

Посевные площади ржи за последние 5 лет сократились более чем наполовину (на 1 млн га). Рассматривается значение культуры и направления интенсификации селекиии в качестве здорового и профилактического источника пищи, а также ценного компонента в рачионах сельскохозяйственных животных. Проведен анализ современного реестра селекционных достижений в сравнении с другими культурами. В связи с запросами современных перерабатывающих отраслей и стремлением к повышению качества жизни населения нужно ориентироваться на создание сортов разнопланового использования.

Ключевые слова: озимая рожь, селекиия, сорта, урожайность, адаптивность.

\section{Current realities of rye production and problems of breeding science}

Mira Leonidovna Ponomareva, D. Sc. (Biol.), chief research; Sergey Nicolaevich Ponomarev*, D. Sc. (Agr.), chief research.

Tatar Research Institute of Agriculture, FRC Kazan Scientific Center of RAS, ul. Orenburgskii trakt, 48, Kazan, 420059, Russian Federation.

*e-mail: smponomarev@yandex.ru

Rye acreage has been reduced by more than half (by 1 million ha) over the past 5 years. The importance of culture and direction of breeding intensification in the quality of healthy and preventive food source, as well as valuable component in the diets of farm animals are considered. The analysis of modern Register of selection achievements in comparison with other crops is carried out. Due to the demands of modern processing industries and the desire to improve the quality of life of the population, it is necessary to focus on creating varieties of diverse use.

Keywords: winter rye, selection, varieties, yield, adaptability. 
Посевные площади ржи в 2019 году составили 871,6 тыс. га, в т.ч. озимого образа жизни 95,5 \% от всех посевов, яровой ржи - 0,5 \%. За год по отношению к 2018 площади сократились на 11,1 \%, а за 5 лет - более чем наполовину (на 1 млн га) (https://ab-centre.ru/news/posevnye-ploschadi-rzhi-v-rossiiitogi-2019-goda). По отношению к началу рассматриваемого периода размеры посевов сократились на 2,76 млн га. Лидерами среди регионов РФ по объему площадей ржи в 2019 году являются Оренбургская область (18,9%); Республика Башкортостан (13,7 \%); Республика Татарстан (9,3%); Саратовская область (7,3\%); Волгоградская область $(6,4 \%)$. Также в десятку областей со значительными площадями ржи вошли Кировская область, Удмуртская Республика, Брянская область, Алтайский край и Нижегородская область (2,2-6,0 \% от ржаного клина).

Без посевов озимой ржи немыслима современная адаптивно-ландшафтная система земледелия. Озимая рожь не требует при своем производстве высоких затрат, менее требовательна к влаге, кислотности почвы и предшественникам, слабее поражается корневыми гнилями и фузариозом колоса. Озимая рожь - одна из наиболее засухоустойчивых хлебных культур, которая стабилизирует сбор зерна в годы с сильными летними засухами. Не зря наибольшие посевные площади ржи имеются в областях с резкой континентальностью климата, наиболее страдающих от аридных условий: Республики Татарстан и Башкортостан, Оренбургская, Саратовская и Волгоградская области [1].

Поэтому ориентируясь на глобальные и локальные изменения климата, большое значение приобретают сорта озимой ржи, способные с наименьшими потерями выдерживать действие абиотических и биотических стрессов, обеспечивая при этом стабильный урожай зерна высокого качества.

С давних времен ржаной хлеб из муки грубого помола для российского народа был не только продуктом питания, но и постоянным мощным профилактическим средством против ожирения, атеросклероза, ишемической болезни, нервных и онкологических заболеваний. В последние годы стремление к здоровому образу жизни находится в центре внимания, и спрос на здоровые продукты питания растет. Дефицит микроэлементов, витаминов группы В и Е, минеральных веществ выявлен практически во всех регионах страны и во всех группах населения, что непосредственно сказывается на росте сердечно-сосудистых заболеваний. Рожь обладает широким спектром защитных свойств для профилактики и лечения метаболического синдрома и сопутствующих заболеваний, в том числе болезней сердца, сахарного диабета 2 типа, дисфункций кишечника и некоторых видов рака. Последние исследования показали, что рожь снижает развитие детской астмы, способствует похудению, позволяет предотвратить образование язв и камней в желчном пузыре, оптимизировать метаболические параметры клеток [2]. 
Оздоровительные свойства ржи связывают, в первую очередь, с присутствием большого количества клетчатки и так называемого «комплекса ржаных волокон», представляющих собой серию различных биологически активных соединений. Этот злак содержит 73 \% нерастворимых пищевых волокон, а доля растворимых волокон на 27 \% выше по сравнению с другими зерновыми культурами [3]. Основными компонентами диетических волокон ржи являются арабиноксиланы, олигосахариды, лигнаны, фитаты, фенольные кислоты, алкилрезорцинолы. Зерно ржи следует использовать в максимально больших количествах при производстве здоровых и функциональных продуктов питания, обогащенных биологически активными компонентами, поскольку эти вещества защищают от многих заболеваний, связанных с питанием [4]. Необходимо более широкое использование ржи в пищевых продуктах, чтобы повысить ее роль в сбалансированном ежедневном рационе. Несколько крупных продовольственных компаний уже работают над проблемой увеличения потребления здоровой ржаной пищи. Ржаные продукты также могут быть перспективными с точки зрения создания новых продуктов, обеспечивающих экологически устойчивый источник белка (www.nordicryeforum.info). Селекция сортов ржи, богатых пищевыми волокнами, может удовлетворить эту новую социальную потребность. Кроме того, использование новейших аналитических методов, в том числе омиксных технологий, является чрезвычайно важным и, как ожидается, обеспечит крупные прорывы в исследовании ржи как полезного и профилактического источника пищи.

Важным направлением диверсификации зерна ржи, безусловно, является его использование в рационах сельскохозяйственных животных $[5,6]$. Зернофуражная рожь особенно сильно востребована в областях Нечерноземной зоны, а также в Поволжье и на Урале, где эта культура традиционно возделывается, а производство зерна других кормовых культур (кукуруза, соя) невозможно по климатическим причинам [7]. Создание низкопентозановых и кормовых сортов озимой ржи - одна из приоритетных задач современной селекции. Дальнейший прогресс в расширении площадей возделывания ржи связывается с увеличением рынка сбыта и расширением направлений ее использования. Это вызвало насущную необходимость своевременной разработки новой стратегии селекционно-генетического улучшения ржи.

В Государственный реестр селекционных достижений, допущенных к использованию в Российской Федерации на 2019 год, включено 84 сорта и гибрида озимой ржи, в том числе один кормовой (Бухтарминская) и 9 тетраплоидных (Веснянка, Влада, Жнейка, Жнивень, Пуховчанка, Сибирь, Сибирь 4, Славида, Тетра короткая). В последние годы в реестре значительно увеличилось число гибридов озимой ржи. Первые $\mathrm{F}_{1}$ гибриды были включены в реестр РФ в 2008 и 2009 годах - Первисток (Институт растениеводства им. В.Я. Юрь- 
ева НАAН Украины) и Пикассо (KWS LOCHOW GMBH). В последующее десятилетие количество $\mathrm{F}_{1}$ гибридов озимой ржи увеличилось до десяти, большая часть из которых создана в Германии. В Государственный реестр также включены рожь многолетняя Державинская 29 (Ставропольский НИИСХ) и рожь яровая Онохойская (Бурятский НИИСХ).

Примечательно, что в реестре появились сорта нового направления использования, которые выделены в особую группу - сорта с низким содержанием пентозанов в зерне. Первые 3 таких сорта были районированы в 2016 г. - Подарок (Татарский НИИСХ), Вавиловская (ВИГРР им. Н.И. Вавилова, Тульский НИИСХ), Берегиня (ВИГРР им. Н.И.Вавилова, ФГУП «Котласское»). Следом за ними в 2018 г. были районированы еще 2 сорта - Красноярская универсальная (ВИГРР им. Н.И.Вавилова, ФИЦ «Красноярский НЦ СО РАН») и Янтарная (ВИГРР им. Н.И.Вавилова, Уральский НИИСХ). Все эти низкопентозановые сорта были созданы на исходном материале профессора В.Д. Кобылянского.

За период 2011-2019 годов сортовой реестр РФ пополнился 26 сортами и 8 гибридами озимой ржи. Однако, если учитывать современные рыночные условия и сравнивать интенсивность передачи сортов ржи с интенсивностью по другим зерновым культурам, то можно констатировать, что новых сортов ржи создается явно недостаточно из-за чего сортосмена происходит медленно, а производитель сталкивается с ограниченным выбором сортов. Например, в таких традиционных для возделывания озимой ржи регионах России, как Волго-Вятский, Средневолжский и Уральский, количество рекомендуемых для возделывания сортов ржи (7-27) уступает сортименту пшенице (52-90 сортов озимой и яровой) и ячменя (22-51 сортов). В ближайшие годы необходимо интенсифицировать селекционную работу по созданию новых конкурентоспособных сортов озимой ржи.

Таким образом, в последние годы проявляется беспрецедентная тенденция уменьшения посевных площадей озимой ржи. Главными аргументами в пользу возделывания ржи является ее уникальная социально-экономическая значимость в производстве продуктов питания, здоровья человека, агроэкосистемы и окружающей среды. В условиях глобальных изменений, происходящих в экономике, науке и технологиях, климатических флуктуаций и биополитике роль страховой культуры ржи также чрезвычайно важна. В связи с запросами современных перерабатывающих отраслей и стремлением к повышению качества жизни населения нужно ориентироваться на создание сортов разнопланового использования.

\section{Список литературь}

1. Пономарева М.Л., Пономарев С.Н., Тагиров М.Ш. Динамика факторов производства и использования зерна ржи в Российской Федерации и Республике Татарстан // Земледелие. 2014. - №.8. - С. 6-9. 
2. Jonsson K. et al. Rye and health-Where do we stand and where do we go? // Trends in Food Science \& Technology. 2018. - T.79. - C. 78-87.

3. Feng G. Rye // Bioactive Factors and Processing Technology for Cereal Foods. Springer, Singapore, 2019. - P. 151-169.

4. Meija L., Krams I. Rye // Whole Grains and their Bioactives: Composition and Health. 2019. - C. 169-208.

5. Зверкова 3.Н. Использование зерна озимой ржи в кормлении крупного рогатого скота // Кормопроизводство. 2008. - № 9. - С. 24.

6. Аллабердин И.Л. Зерно озимой ржи в комбикормах для дойных коров // Достижения науки и техники АПК. 2010. - № 1. - С. 46-48.

7. Гончаренко А.А. Современное состояние производства, методы и перспективные направления селекции озимой ржи в РФ // Озимая рожь: селекция, семеноводство, технологии и производство. Уфа, 2009. - С. 40-60.

DOI 10.18699/GPB2020-99

\section{Получение и перспективы использования дигаплоидов ячменя обыкновенного (Hordeum vulgare L.) (обзор)}

Попова К.И., м.н.с., аспирант.

СибНИИРС - филиал ИичиГ СО РАН; НГАУ, Новосибирск, Россия.

E-mail:popova.k.i@mail.ru

Ячмень обыкновенный (Hordeum vulgare L.) является важной сельскохозяйственной культурой, которая находит применение в пивоварении, используется в кормовых и продовольственных изелях. Селекция ячменя в условиях Западной Сибири осложнена природно-климатическими особенностям. Для упрощуения и ускорения селекционного процесса, а также для решения фундаментальных генетических задач, используют дигаплоидные формы. Такие формы ячменя могут быть получены в условиях іп vivo и іп vitro. В настоящее время, в странах Европь существует большое число дигаплоидных форм ячменя обыкновенного, которые вовлекаются в селекиионные программы. Запуск подобных программ в Западной Сибири требует создание собственной базы по синтезу дигаплоидных форм ячменя.

Ключевые слова: дигаплоид, ячмень обыкновенный, Hordeum vulgare L., in vitro, культура пьльников, культура изолированных микроспор.

\section{Obtaining and prospects for the use of digaploids of barley}

(Hordeum vulgare L.) (review article)

Popova Karina Igorevna ${ }^{1,2}$

${ }^{1}$ SibRIPP\&B - branch ICG SB RAS; ${ }^{2}$ Novosibirsk State Agrarian University, 